\title{
Sediment budget of the Napo River, Amazon basin, Ecuador and Peru
}

\author{
A., Laraque ${ }^{1}$, C., Bernal ${ }^{2}$, J. L. Guyot ${ }^{3}$, E., Armijos ${ }^{4}$ L., Bourrel ${ }^{2}$, Darrozes², J. \\ Christophoul $^{2}$, F. \\ 1 IRD - BP 8006, 97259 Fort de France, France \\ 2 Université de Toulouse; UPS (SVT-OMP); LMTG, Toulouse, France \\ 3 IRD (UR154 LMTG) - Brasilia, Brasil \\ 4 INAMHI -700 Iñaquito y Correa, Quito, Ecuador
}

\begin{abstract}
The upstream-downstream sediment budget along the Napo River $\left(100,520 \mathrm{~km}^{2}, 6,300\right.$ $\mathrm{m}^{3} \mathrm{~s}^{-1}$ ) was studied in the Andean Foothill of Ecuador, at the west of the Amazon basin. A comparative study was made, during 4 hydrological cycles (2001-2005) for 3 hydrological stations located upstream; and during 1 hydrological cycle (2004-2005) for the fourth one located near the mouth of the Napo River (region of Iquitos in Peru). This analysis showed an unusual increase in the concentration of suspended sediment recorded for the western part of the Amazon plain. These relatively high erosion rates for a floodplain basin $\left(1,160 \mathrm{t} \mathrm{km}^{-2}\right.$ year $^{-1}$, i.e. $47 \%$ of TSS export at the exit of Ecuador) can be explained by a stepper slope than in the rest of the Andean foothills, where typically sedimentation phenomena are predominant.
\end{abstract}

Here, the tectonic uplift causes the Pastaza Megafan's existence. This progressively diverts the course of Napo River towards north and also provokes the remobilisation of fine fluvial deposits. Moreover, this geodynamic trend is completed by the impact of volcanic eruption, earthquakes and landslides. The combination of these phenomena, so common in the region, has provided a large sediment transfer, not only at present but also in the past, as can be confirmed by the presence of incised terraces, mainly formed by volcanic materials. 
Then, these results were compared with a similar study carried out further South in the Madeira Basin at the foot of the Bolivian Andes. These studies show the spatio-temporal variability of the relation between sediment transfer and geodynamic processes at the Andean Piedmont.

Key Words : Amazon River basin, Sediment yield, Tectonics, Pastaza Megafan, Andes, Napo basin

\section{INTRODUCTION}

The Amazonian basin (Fig. 1), the largest on the planet with $6,2.10^{6} \mathrm{~km}^{2}$, provides $6,6.10^{12} \mathrm{~m}^{3}$ of water (Molinier et al., 1996) and $800.10^{6}$ tons per year of sediment to the Atlantic Ocean (Guyot et al., 2005). It represents, respectively, 16.6 and $6 \%$ of the discharge and sediment planet contribution from the continents to the oceans, according to the world values of $39,710^{12} \mathrm{~m}^{3}$ of water (Baumgartner et Reichel, 1975) and 13,500 $10^{6}$ tons of sediment (Milliman and Meade, 1983). Most of the sediment discharged (95\%) to the Atlantic Ocean by the Amazon River comes from the Andes Mountains although the range only covers $12 \%$ of the surface area of the Amazon basin.

On the brazilian side of the Amazonian basin, the sedimentary transport has already focused many works aimed at quantifying them (Gibbs, 1967, Meade et al., 1985, Dunne et al., 1998, Filizola, 2003, Moreira-Turcq et al., 2004, Guyot et al., 2005 and Laraque et al., 2005). The sediment transport processes from the rivers draining the western part of the amazonian plain located at the Andean Cordillera Piedmont are essentially reported in Bolivia at the southwest of the basin. Here, important sediment deposits are observed (Guyot et al. 1996), within a geodynamic context of subsidence (Horton et De Celles, 2001, Cornelius et al., 2005, Baby et $a l .$, in press). 
Further north, in the Peruvian and Colombian part of the Amazonian basin, a lack of studies of the actual suspended sediment yield is evidenced, due to the distancing of these regions, at times of difficult access and /or to their insecurity.

However some recent works in tectonics, geodynamics and geomorphology have been carried out in the eastern ecuadorian and northern peruvian Andes piedmont, through some field campaigns and analysis of satellite images. These studies point out a tectonic uplift, that started at Neogene, and its consequences over the relief and erosion (Burgos et al., 2004, Christophoul et al., 2002a \& b, Bès de Berc et al., 2005). This tectonic deformation has led to an increase of the river's slopes. Consequently, these ones have tended to regain its equilibrium profile by increasing their valleys (Bès de Berc, 2003). In fact, a first exploratory work of the sediment flux through the Ecuadorian Amazon, during a single hydrologic cycle, evidenced an actual erosive process in that region (Laraque et al., 2004). The same process was observed more downstream in the Peruvian part of Napo basin (Guyot et al., 2007).

Along different mountain ranges of the planet in general (Hovius, 1998, Leeder et al., 1998, Hsieh et Knuepfer, 2001), and in South America in particular, some works (Weng et al., 2002, Keefer et al., 2003, Aalto, et al., 2003) have already put in evidence the dependance of fluvial transport with climate and tectonic. These relations complete those well-known processes of sediment transfer (erosion and/or transport and/or sedimentation) with the physiographic characteristics (climate, morphology, vegetation, pedologic coverings, geology, land usage, drainage network, ....) of mountainside basins, as illustrating by Restrepo et al., (2006) in the Magdalena basin in Colombia. Notwithstanding, theses aspect are not still studied for the eastern piedmont of the Ecuadorian Andes and its plains, a region known for its great geodynamic activity, subject to frequent and continuous seismic and volcanic episodes (Yepes et al., 1996) and numerous landslides (Zevallos et al., 1993).

In order to resolve this problem, a first multiannual monitoring attempt of the sediment flow 
was carried out on the hydrographic basin of the Napo River which drains the eastern piedmont of the Ecuadorian Andes. The data come from the HYBAM programme (www.mpl.ird.fr/hybam), which started in 2001 in Ecuador.

This work has been organized in the following way: - Part 2, a description of the studied region; - Part 3, data and methods used; Part 4, a result-based discussion. This last one addresses questions regarding spatio-temporal variability that evidenced sediment processes, at the Napo and at the Amazon River basins level.

\section{STUDIED AREA}

\section{Geography}

The whole Napo River drainage basin is situated between $00^{\circ} 10^{\prime} \mathrm{N}$ and $01^{\circ} 30^{\prime} \mathrm{S}, 75^{\circ} 20^{\prime}$ and $78^{\circ} 40^{\prime} \mathrm{W}$ with an altitude ranging from 100 to 6,300 m.a.s.l. Its area covers $100,500 \mathrm{~km}^{2}$, distributed among Ecuador (59.6\%), Peru (40\%) and Colombia (0.4\%). On these latitude, the ecuadorian part of the Andean Cordillera is the narrowest within the Central Andes and presents important geodynamic activity (volcanic and seismic).

In Ecuador, where this study is more avanced, the Napo basin covers an area of $27,000 \mathrm{~km}^{2}$, i.e. equivalent to $20 \%$ of the eastern part of this country. The Ecuadorian part of the Napo basin crosses the "Cordillera Real"; whose eastern side has steep slopes that descend from 6,000 to 500 masl over only 100 kilometers.

\section{Geology}

The Napo River drainage basin is located in the eastern sediment basin of Ecuador and Peru, which has sustained an uplift and tectonic deformation since Neogene (Bès de Berc, 2003). Drained lands in Ecuador, are essentially made up of a series of volcano-sediments; while in Peru drained lands are fluvial and tidal deposit (Räsänen et al., 2005, Wesselingh et al, 2006). The course of Napo River get around the northern limit of the "Pastaza Megafan" situated 
between $0^{\circ} 00^{\prime}$ and $5^{\circ} 00^{\prime} \mathrm{S}$ and $73^{\circ} 00^{\prime}$ and $78^{\circ} 00^{\prime} \mathrm{W}$ with an altitud between 90-300 m.a.s.l. and an area of $40300 \mathrm{~km}^{2}$ (Bernal et al., personal communication). It is the greatest tropical alluvial fan in the world according to Räsänen et al., (1992).

\section{Vegetation covers}

Below $500 \mathrm{~m}$ high, at the exit of mountainous reliefs, a fairly flat and homogeneous forested ecosystem is found, which can be defined as part of the amazonian plains. This ecosystem covers the main part (82\%) of the total surface of the Napo basin and it is located in Ecuador and Peru. The rest (18\%) in Ecuador is constituted by the Andean Cordillera closing off the basin on the west (Fig. 1). The andean vegetation covers are composed by "puna" and "paramo", which are typical short vegetation covers like a kind of highland toundra.

\section{Climat}

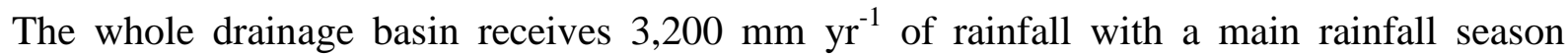
between May and June, with a monthly maximum of $330 \mathrm{~mm}$, and a second rainfall season between September and November with a monthly maximum of $250 \mathrm{~mm}$ (Fig. 2).

The Ecuadorian Napo region receives high precipitation $\left(2,900 \mathrm{~mm} \cdot \mathrm{yr}^{-1}\right)$ and presents very irregular runoff regimes, characterized by flash floods, reflecting their extreme sensitivity to rain events (Laraque et al., 2007). The same authors showed that rainfall and discharge regimes are highly variable in space. They depend on altitude so that different regimes may be found in the same basin. At high locations, rainfall presents a marked bimode, with a maximum in April and October and a minimum in July-August and in January. This rainfall seasonality is associated with the annual progress of the sun and with the seasonal variability of the zonal wind that uplifts moist air from the Amazon basin. In small to medium upper basins, two discharge maxima occur along with the two rainfall maxima. However during the 
July-August period, discharge values do not decrease, probably and mainly because of ground water running, of the dominating upper highlands "paramo" formation. In the lowlands, rainfall and discharge seasonal variability is very weak. Relative maxima are observed in April for rainfall, June for discharge; secondary small maxima are observed in October (rainfall) and November (discharge).

On the Peruvian part of the Napo River basin, the interanual rainfall average is 3,310 mm. $\mathrm{yr}^{-1}$.

\section{Hydrology}

Close to 6,000 m.a.s.l. of altitude, the origin of the Napo River is from the thawing of glaciers which covers the Cotopaxi (5,897 m.a.s.1.), Antisana (5,700 m.a.s.1.) and Llanganates (4,571 m.a.s.1.) volcanoes. Within the first half of the river course in ecuadorian territory, the Napo River presents a torrential to turbulent behavior. It leaves Ecuador at an altitude of 189 masl and at about $400 \mathrm{~km}$ from its headwaters, it receives the contribution of the Aguarico River and enters Peru to travel $600 \mathrm{~km}$.

At the river mouth near Bellavista gauging station, the Napo River drains an area of 100,520 $\mathrm{km}^{2}$ and presents a mean annual discharge of $6,300 \mathrm{~m}^{3} \mathrm{~s}^{-1}$ (that mean $62 \mathrm{l} \mathrm{s}^{-1} \mathrm{~km}^{2}$ ) which corresponds to $4 \%$ of the Amazon River recorded at Obidos, an hydrometric station located the furthest downstream in Brazil.

The Napo River is the main eastern river of Ecuador (Fig. 1) with an annual discharge of $2,210 \mathrm{~m}^{3} \mathrm{~s}^{-1}$ at Nuevo Rocafuerte station on the outlet of this country. Its area is $26,860 \mathrm{~km}^{2}$, with a solid discharge equal to $821 \mathrm{~s}^{-1} \mathrm{~km}^{2}$. In Ecuador, the Napo River drains almost 3\% of the whole Amazonian catchment.

The Napo is a «white water» river type. Typically, these rivers have high levels of total suspended sediments, due to the mechanical erosion of the Andean chain. In fact, according to Guyot (2007), the sediment transport's Napo River is estimated at $4910^{6}$ ton $_{\text {year }}{ }^{-1}$, which 
corresponds to $6 \%$ of the sediment flow passing through Obidos station in Bresil.

\section{METHODS AND DATA}

To understand the sediment dynamic at the Andean Piedmont of the Napo River basin, an integrated approach using hydrology and geomorphology was used. The hydrology was studied through out the implementation of hydrologic and sedimentologic measuring stations, along the course of the Napo River, which drift off perpendicularly to the Andes to penetrate the Amazonian plains. Then, a comparative upstream-downstream study of sediment budgets was performed using the collected data.

Figure 1 shows the location of the stations used on the main node of this schematic fluvial system. San Sebastian (SEB) and Francisco de Orellana stations (FDO) control the output of the Andes, and Nuevo Rocafuerte station (ROC) closes the basin at the outlet from Ecuador. In Peru, Santa Clotilde (CLO) is located after the confluence with Curaray River and, finally, Bellavista station (BEL) controls the whole basin (Table 1). Besides, a field scientific crossing along the Napo River during the falling stage (October, 2004) has enabled the study of the longitudal evolution of the TSS discharges, concentrations and flows (Fraizy et al., 2005).

The geomorphology was studied through out the longitudinal profile and the spatial variations of percentage in sand, water and vegetated island. The construction of longitudinal profile and stream slope is another result of the field scientific crossing along the Napo River on October 2004. We used for this DGPS survey, a base station and cinematic station with bifrequencies AShtech ZXTREM and Trimble 5700 receptors (Bourrel et al, 2007). This survey covered the Napo River from Puerto Misahualli, in the Subandean Zone, to the confluence with the Marañon River along 1100 km (Fig. 3), 13500 measurements were realized with an elevation accuracy smaller than $0.5 \mathrm{~m}$ and a mean RMS (Root Mean Square) of $0.1 \mathrm{~m}$.

Spatial variations of percentage in sand, water and vegetated island was evaluated using 
Landsat images (TM and ETM+, spatial resolution $30 \mathrm{~m}$ ) of 1986, 1989, 1995, 1996 and 2002. They were collected during the falling stage on the reach between FDO and ROC stations. The limitations of satellite coverage required us to divide the segment ROC -FDO in two areas (ROC-X / X-FDO, Fig. 3). Both set of images were studied for the same months to point out and quantify the sand islands changes in term of sedimentary supply. To quantify these variations of percentage on the Napo River, we classified satellite images through the parallelepiped threshold. In order to do that, three homogenous classes, taking into account spectral signature, were defined as: water, sand and vegetated island.

\section{1 - WATER LEVEL AND DISCHARGE MEASUREMENTS}

In these gauging stations, the observers carried out daily or twice a day limnimetric measurements. Frequent gaugings were carried out along five hydrological cycles using a 1,200 kHz ADCP (Acoustic Doppler Current Profiler) to establish gauging curves.

\section{2 - SUSPENDED SEDIMENT SAMPLING AND FLOW CALCULATIONS}

At the three Ecuadorian stations water surface samples were taken in the middle of the river by an observer, every 10 days since 2001 . The samples were filtered using $0.45 \mu \mathrm{m}$ cellulose acetate filters to separate the TSS. Cerón (2004) and Laraque et al., (2004) studied the relations between these surface TSS concentrations and the average of TSS concentrations in the cross section. As described by Filizola \& Guyot, (2004), we used a point sampling protocol to determinate the TSS concentrations in different points of the cross sections. This was made at different stages during several complete annual hydrological cycles.

Figure 4 shows the established relation for SEB and FDO stations, located at the exit of the Andean Piedmont. The calculated mean TSS concentrations in these stations are only 5\% higher than those TSS concentrations taken by the observers at the surface. This is due to the 
weak heterogeneities of velocities and specific TSS concentrations within the measured profiles, which illustrate much more turbulent flows marked by numerous swirls, assuring a continuous mixing of particles in suspension. Further downstream in the Amazonian basin near the ROC station, the river sections become much more heterogeneous with profiles characterized by higher velocity gradients and TSS load (Filizola, 2003, Laraque et al., 2005). During the hydrologic cycles, the peaks of TSS concentrations precede flood peaks at times, overlapping them or occurring afterwards. The shift of flood and TSS peaks is larger in the middle of the Amazonian plains where the former always precedes the latter, at times for many months (Laraque et al., 2005). This observation invalidates the use of relations (TSS = $\mathrm{f}(\mathrm{Q})$ ) to calculate sediment discharge. To overcome this obstacle, a frequency of 10-days samplings, much more adapted to the behaviour of these rivers, has been implemented. Such a frequency, applied over many hydrologic cycles, enables the obtaining of more accurate calculation of the TSS yields.

As the frequency of the discharge daily values for the studied stations is higher than those of TSS (10 days), the intermediate TSS values were calculated by linear interpolation and multiplied by the discharge to obtain the suspended load. It is possible to obtain a daily suspended sediment yield using the Hydraccess software (www.mpl.ird.fr/hybam/outils/hydraccess.htm).

The monthly and annual sediment flows come from the arithmetic mean of corresponding time series. Monthly and annual TSS concentrations are calculated by dividing the corresponding suspended sediment yield by discharges.

The 4 annual April-March cycles of the 2001-2005 period studied in Ecuadorian station and the April-March cycles of the 2004-2005 period studied in Peru (BEL station), were used to compare the stations budget from upstream to downstream Napo River. The results are presented in tables 2 and 3. 


\section{RESULTS \& DISCUSSION}

\section{1 - Temporal Variability of suspended sediment yields}

For the studied stations of the Napo basin, the monthly hydrograms are slightly bimodal with a main period of high waters (from February to September) finishing between May and July, and a short second season of floods during, in general, from mid-November to January.

Table 2 shows the range of variation of discharges, TSS concentrations and flows studied, at daily, ten-days and monthly time spans throughout the entire group of stations during the studied period. The 10-day instantaneous TSS concentrations vary between 2 and 2,806 $\mathrm{mg} \mathrm{l}^{-1}$ according to the station and season. As much as for the extreme values as for the mean ones, those of SEB are the highest of the four studied stations. Regarding the reports of the extreme concentrations for each station, those at ROC and at SEB are identical for the max/min ratios (281). This ratio reports along with the one at FDO (478) are much more superior to that of BEL (11). The higher ratios of the three first stations are due to their weak minimal TSS concentrations in low water periods, between 2 and $10 \mathrm{mg} \mathrm{l}^{-1}$, which are common in mountainous rivers. The extreme daily discharges ratios, which are smaller than those of TSS concentrations, are in a diminishing order equal to 13 (FDO), 10 (BEL), 7 (SEB) and 5 (ROC). At a monthly time span, these extreme ratios are slightly reduced.

The two annual cycles from april 2001 to march 2002 and from april 2004 to march 2005 are similar with important increase (around 50\%) of upstream-downstream TSS concentrations and suspended sediment yields (Table 3). On the other hand, the two other cycles from april 2002 to march 2003 and from april 2003 to march 2004 show a weaker increase of upstreamdownstream TSS concentrations (10 to 30\%) and suspended sediment yield.

Figure 5a shows the monthly variability of the upstream-downstream suspended sediment yield in the ecuadorian part of the Napo basin (ROC-SEB-FDO) during the 2001-2005 period studied. It shows the important temporal variations marked essentially by two irregular 
erosion phases (April, 2001-October, 2002 and May, 2003-April, 2005) alternated with two sedimentation phases of weaker amplitud (November, 2002-April, 2003, and May, 2005September, 2005).

Figure $5 \mathrm{~b}$ shows the monthly variability of the upstream-downstream suspended sediment yield in the peruvian part of the Napo basin (BEL-ROC) during the common July 2004 september 2005 period studied. This positive budget probably comes from the two main tributaries: the Aguarico and Curaray rivers, unfortunately poorly studied. On the left bank, at the north part of the Napo basin, the Aguarico River drains in its upstream reach, the Andean cordillera. On the right bank, the Curaray River drains a vast ancient alluvial plains in uplift process, which originates the Pastaza Megafan.

\section{2 - Spatial variability of actual sediment transfers}

During the studied period, the Andean part of the Napo basin controlled by FDO and SEB stations, produced an interannual mean of $1210^{6}$ ton year $^{-1}$ of TSS, but a total of $22.610^{6}$ ton year $^{-1}$ left the Ecuadorian Napo Basin downstream at ROC (Table 3). The area between these stations covers $9,150 \mathrm{~km}^{2}$ and provided a net gain difference of $10.610^{6} \mathrm{t}_{\text {year }}{ }^{-1}$ of TSS. This amount corresponds to $47 \%$ of the Napo River sediment yield at ROC. Also, the specific sediment yield from the lower part of the basin is about $1,160 \mathrm{t} \mathrm{km}^{-2}$ year ${ }^{-1}$. This upstreamdownstream increase of suspended sediment yield stems from an increase of Q and TSS concentrations. These variations seem very high, considering there are almost no uplands in this intermediary area, which is protected by a dense forest cover.

If on one hand, the interannual budgets of the studied period indicate a sediment production (erosion) of $10.610^{6}$ ton $\mathrm{yr}^{-1}$ for the Andean Piedmont located between SEB+FDO and ROC, on the other hand, the annual budgets are very variable, with erosion ratios which are consecutively in the following order $16,5,6.6$ et $14.510^{6}$ ton $\mathrm{yr}^{-1}$ for the 4 annual cycles 
studied.

The interannual erosion rate (TSS in $\mathrm{t} \mathrm{km}^{-2} \mathrm{yr}^{-1}$ ) corresponds to the discharge or sediment yield normalized for the drainage area. These are the only units which enable the comparison among them of the basin transport dynamics, whether it is due to erosion or sedimentation. Although the Coca basin has the lowest specific discharge $\left(661 \mathrm{~s}^{-1} \mathrm{~km}^{2}\right)$ of the sub basins studied in Ecuador, and the smallest watershed area (one third of the watershed area controlled by FDO), it presents the maximum specific sediment rate $\left(1,062 \mathrm{t} \mathrm{km}^{-2}\right.$ year $\left.{ }^{-1}\right)$, twice the Napo basin at FDO $\left(515 \mathrm{t} \mathrm{km}^{-2}\right.$ year $\left.^{-1}\right)$, and the interannual suspended sediment yield are similar at the two stations. This result stems from the high TSS concentrations of SEB (487 $\left.\mathrm{mg} \mathrm{l}^{-1}\right)$, three times the value of FDO $\left(166 \mathrm{mg} \mathrm{l}^{-1}\right)$ (Tables $1 \& 3$ ).

Such a difference encountered in a specific sediment yield between these two rivers can be explained from their longitudinal profile. The Coca River rises in the eastern flanks of Reventador volcano, and flows for $209 \mathrm{~km}$ on the Subandean with a steepest slope of $38.8 \mathrm{~cm}$ $\mathrm{km}^{-1}$. The Napo River is $1,075 \mathrm{~km}$ long, ranging $301 \mathrm{~m}$ in altitude (404-103 m above sea level) from Puerto Misahualli, in the Subandean, toward the confluence with Marañón River, with a strong variation of its slope (Fig. 3). Notwithstanding, upstream crossing the foothills of the Subandean Zone, both rivers profile (Coca \& Napo river) are very steep and characterized by a strong slope ranging from $1.7 \mathrm{~m} \mathrm{~km}^{-1}$ to $35 \mathrm{~cm} \mathrm{~km}^{-1}$. The difference begins at FDO, when the Coca River debouches into Napo River, and the last one shows a pronounced break in the profile that marks the beginning of Amazonian basin with a drop in the mean slope of $35 \mathrm{~cm} \mathrm{~km}^{-1}$ (Table 1). This slope stays roughly constant for the first $300 \mathrm{~km}$ in a transition area between FDO and ROC, even if some slope breaks can be observed due to the transverse profiles for navigation channel optimisation (Fig. 3). Likewise, this slope is more than 10 times higher than in the rest of the Amazon basin, and therefore it promotes a water velocity that is strong enough to create a relatively rectilinear course of the Napo River 
as it leaves the Andes (Fig. 1). The increase in velocity results in an increase in the erosive and transport capacity of the river. Consequently, in the plains, the value for specific erosion is only a little smaller than in the mountains (1,160 against $1,577 \mathrm{t} \mathrm{km}^{-2}$ year $\left.^{-1}\right)$ (Table 3$)$. This sedimentary remobilization is applied on fluvial deposits essentially constituted by fine sand particles like shown by the $\mathrm{d} 50(0,2$ to $0,5 \mathrm{~mm})$ of the Hybam Napo'04 field trip (Fraizy et al., 2005). These values are intermediates between those measured by Guyot et al., (1999), on the Andean outlet (d50 30 mm) and the very flat plain "Llanos" (d50 11 mm) area in Madeira drainage basin in Bolivian Amazonia.

These observations were also confirmed by the results of the scientific field trip along the Napo River, which took place during the falling stage of October, 2004 (Table 4 and Fig. 1). In Ecuador, the TSS concentrations and suspended sediment yield increased upstream-

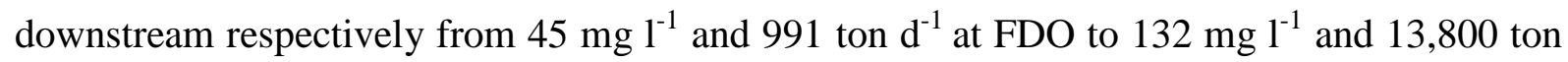
$\mathrm{d}^{-1}$ at ROC. The suspended sediment yield gained 12,809 ton $\mathrm{d}^{-1}$ between these two stations, stem partially from contributions made from the Coca River $\left(1,778\right.$ ton $\left.\mathrm{d}^{-1}\right)$. The rest $(11,031$ ton $\mathrm{d}^{-1}$ ) is due to the remobilization of old alluvial deposits of the Napo River. This phenomenon's river basin is so relevant in this area considering the weaker TSS concentrations observed in its main tributaries $\left(33.2 \mathrm{mg}^{-1}\right.$ for the Coca River and $24.3 \mathrm{mg} \mathrm{l}^{-1}$ for the Tiputini River), which in reality might have been diluted in the Napo River waters.

But, since a flood was occurring during the field trip, it is necessary to study with caution the measured values. It could be the reason for the relatively high SM concentration of $199 \mathrm{mg} \mathrm{l}^{-1}$. The suspended sediment yield gained 61,550 ton $\mathrm{d}^{-1}$ between BEL-ROC, steam mainly from the increasing of SM concentration during the flood rather that from the tributaries input that reached only 13,300 ton $\mathrm{d}^{-1}$.

The next reach of Napo profile, between BEL and ROC (Fig. 3), are characterized by a general diminishing in the mean slope $\left(11 \mathrm{~cm} \mathrm{~km}^{-1}\right)$, which is three time smaller that the one 
at ROC-FDO section. Nonetheless, we obtain always the same conclusions about a mean positive sediment budget encountered during an entire yearly cycle (Fig. 5b). It amounts to $19.8 \mathrm{t} \mathrm{day}^{-1}$ of TSS, coming from a stream of $540 \mathrm{~km}$ long which drained an area of 73,660 $\mathrm{km}^{2}(73.3 \%$ of the total basin area). These values correspond to a specific discharge of 64.81 $\mathrm{s}^{-1} \mathrm{~km}^{2}$ and a specific solid discharge of $268 \mathrm{t} \mathrm{km}^{-2} \mathrm{year}^{-1}$. The fluxes sediment contribution of this intermediate area (BEL-ROC) corresponds to $42.5 \%$ of the Napo River sediment yield at BEL (table 3). This contribution is more related to the high annual discharge of this zone $\left(4,777 \mathrm{~m}^{3} \mathrm{~s}^{-1}\right.$ or $68.5 \%$ of BEL annual discharge) than to its weaker mean SM concentration (13 $\mathrm{mg}^{-1}$, usual feature value in the central Amazonian plain).

As we noted in $\S$ IV. I, after leaving Ecuador, the Napo River receives the contribution of two important tributaries in terms of discharges and TSS, the Aguarico and Curaray rivers. For example, during the scientific field trip of october 2004 (Tab. 4), each one of them presented a discharge of about $800 \mathrm{~m}^{3} \mathrm{~s}^{-1}$ that correspond both to $36 \%$ of Napo River discharge at BEL, with respectively 110 and $60 \mathrm{mg} \mathrm{l}^{-1}$ of TSS. The Curaray catchment and the rest of the drained area of the Napo River in Peru correspond to a relatively flat area covered with rain forest. The other little tributaries totalised less that $500 \mathrm{~m}^{3} \mathrm{~s}^{-1}$ or $12 \%$ of Napor River at BEL, with weak TSS concentrations (17 to $78 \mathrm{mg} \mathrm{l}^{-1}$ ).

These considerations prove that the sediment load which exit the Ecuador country at ROC are totally transported to the mouth of the river near BEL with an increase due to the input coming essentially from the two main tributaries, the Aguarico and Curaray rivers. The Curaray River can present relatively hight TSS concentrations. On june 2002, at the border between Ecuador and Peru at an altitud of 200 masl (similar with the one of ROC), Laraque et al., (2002) measured a discharge of about $800 \mathrm{~m}^{3} \mathrm{~s}^{-1}$ for about $200 \mathrm{mg}^{-1}$ of TSS during a flood in Pavacachy on the Curaray River. These values are similar with the annual mean ones encoutered on the Napo River at FDO at 260 masl and correspond to TSS fluxes of 13,800 ton 
$\mathrm{d}^{-1}$

Finally, in the last $100 \mathrm{~km}$, until its confluence with Marañón River, the Napo flows with a weak slope close to $5 \mathrm{~cm} \mathrm{~km}^{-1}$ (Fig. 3), and no erosional power.

\section{3 - Impact of volcanism and geodynamic on TSS}

To better illustrate the lack of interannual reproductivity of the observed sediment transport dynamic, cumulative curves of monthly TSS concentration, discharge and suspended sediment yield have been analysed (Fig. 6). Within a stable basin, the accumulation of suspended sediment yield are similar from one year to the next and regularly increases with some cyclic changes corresponding to alternations of wet and dry seasons (Laraque et al., 1995), like is the case in FDO basin (Fig. 6b). In SEB (Fig. 6a) basin, contrary to the discharges, the TSS accumulations (concentrations and suspended sediment yield) show a sharp rise from November, 2002, affecting ROC station located downstream (Fig. 6c). This slight drop returns to normality 6 months later in May, 2003 (Fig. 6a). This abnormality may be explained due to the El Reventador volcano eruption located in the upstream part of the Coca basin. In fact, on 11/03/2002 the volcano expulsed in a few hours an ash cloud of $15 \mathrm{~km}$ of height estimated at 200 million tons of material (Eissen and Le Pennec, 2002). Studies made on dissolved elements from the Coca River to SEB, Gondran (2004) and Bernal et al., (2007) show that El Reventador ash leaching might have lasted many months. It was increased by the glowing ash clouds and post - eruptive lahars, which are frequent in that wet and sloping region. The latter might be the origin of the succession of the 3 important peaks of TSS to SEB in 2003, which do not always correspond to the strong floods (Fig. 7a \& b). On the contrary of those taking place in May 2001 and in May 2004, which have also provoked curve jolts shown in Figure 6a, correspond to relatively important floods. However, according to the periodic report's "Instituto de Geofísica - Ecuador" (Bernal, personal 
communication), this last one (May 2004) was a secondary lahar produced by important precipitations which have remobilized the ash of El Reventador volcano eruption in 2002. It is quite likely that a great part of the volcanic material carried by the Coca River was deposited downstream from the SEB, an area marked by the rupture of the Andean - Piedmont river slope. Downstream, a number of sandbanks begin to appear and become more frequent along the entire Napo River until ROC station (Fig. 3). Thus, the main erosion process in the downstream basin of the Ecuadorian mountainside temporarily inverted itself in 2003 under the effect of a major and isolated volcanic activity. It then returned to «normality » with a restart of the erosion process showed by an upstream - downstream increase of TSS concentrations.

The hypothesis of an unstable basin, where the sediment budget is disturbed due to catastrophic events, like earthquakes, volcanic eruptions and related eruptions events, is supported by the satellite image analyses (Fig. 8), which allows evaluating the variation percentage of sand on the Napo River. In these areas, the Napo River has only one thalweg but with the presence of multiple moveable sand bars. In the area I (FDO-X, Fig. 3), which is closer to foothills, it is characterized by roughly constant percentages in sand, water and vegetated islands, during the 3 years analysed (1995, 1996, and 2002); with a slight tendency to decline in the sand (drop of 5\%, Fig 8). This fact suggests the presence of an erosion process in the nearest Amazonian plain. The area II (X-ROC, Fig. 3) is characterized by a stronger variation of the percentages in sand, water and vegetation for the 3 years studied (1986, 1989, and 2002; Fig. 8). In the case of the sand, for example, in 1986 the river has an average of $15 \%$, after three years it almost doubled the sand amount (27\%), and finally after 13 years the percentage diminishes to half $(8 \%)$. This variability in the sediment supply from the watershed can be explained by active tectonics and seismicity characteristics of the zone, which in march 1987 provoked two major earthquakes $\left(M_{s} 6.1\right.$ and 6.9), near Reventador 
Volcano. These quakes were the triggering of one of the most catastrophic landslides of the 20th century - worldwide (Schuster, 1996). About $600 \mathrm{~mm}$ of rain fell in the region in the months preceding the earthquakes (Crespo, 1987), and thus land sliding mainly in saturated, residual soils on steep slopes. The slope failures commonly started as thin slides, which rapidly turned into debris avalanches and debris flow that flowed down the slopes into the tributaries and on into major rivers (Schuster, 1996). Estimates of the total volume of earthquake-induced mass wastage ranged from 75-110 million $\mathrm{m}^{3}$ (Crespo et al., 1987; Okusa et al., 1989).

The important geodynamic activity of this part of the Andes, marked by an exceptional density of volcanoes, is directly affected by the tectonic slip of the Nazca Plate under the South American Continent, which caused an uplift of the Eastern Andean foreland. In Napo basin, according to Christophoul et al., (2002a \& b), this previous process has shown an effect in the eastern side of the Ecuadorian Cordillera (at the Miocene-Pliocene limite), by the uplift of ancient alluvial plains originating the Pastaza Megafan. This is evidenced geomorphically, by river incisions and presence of old elevated fluvial terraces upstream FDO, dating from the Neocene period (Burgos et al., 2004, Bès de Berc et al., 2005). The courses of Napo had then progressively deviated towards the northern border. The influence of that morphologic structure and the relatively high slope for a drainage of alluvial plain formations, is the cause for the regular tracking and little meandering of Napo at the entrance of the Amazonian plains. This maintains once again an important hydraulic dynamic.

The observation of the variability of sediment transfer process confirms the preliminary interpretations of Laraque et al., (2004) announcing an erosive process in the region of the Andes which present the most important tectonical dynamic characterized by intensive volcanic and seismic activity. 


\section{5 - Regional comparisons}

The results found on the Peruvian Napo basin were unexpected because its slope indice (11 $\mathrm{cm} \mathrm{km}^{-1}$ ) is similar to the one encountered at the foot of the Bolivian Andes (slope of $8 \mathrm{~cm}$ $\mathrm{km}^{-1}$ ). In this last region, the river (Ex. of Beni/Mamoré River) meanders with low water velocity through an area undergoing subsidence, where they deposit of more that half of their suspended sediment yield (Guyot, 1993, Guyot, et al., 1996, Baby et al., in press). From the analysis of the ${ }^{210} \mathrm{~Pb}$ activity of sedimentary cores, Aalto, et al., (2003) evaluated a rate of

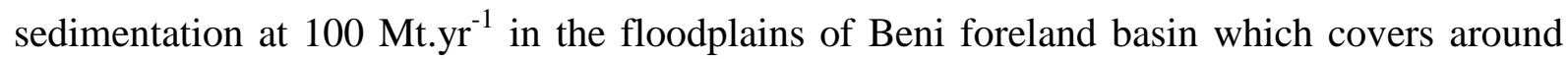
$70,000 \mathrm{~km}^{2}$

More downstream, in central depression of the Amazon basin in Brazil, Laraque et al., (2005), quantifies important sedimentation processes of $0.410^{6} \mathrm{t} \mathrm{yr}^{-1} \mathrm{~km}^{-1}$ in a region where the fluvial slope varies between 3 and $0.3 \mathrm{~cm} \mathrm{~km}^{-1}$. The nature of these processes was already shown by Meade et al. (1985) and Dunne et al., (1998), and illustrates fluvial transport marked by cyclic storage and remobilization stage of sediment, before reaching the Atlantic ocean.

\section{CONCLUSION}

This paper based on collected field data and geomorphological interpretation, enables the proposal of a current sediment transport model for the Andean Piedmont and plains of the Napo basin in Ecuador and Peru. The sediment transfer along the river axis of the Napo River have been studied and quantified: in Ecuadorian part of the Napo basin during four hydrologic cycles from 2001 to 2005; in its Peruvian part during one hydrologic cycle from 2004 to 2005; and during a field scientific trip in October 2004. Regarding the annual budget, erosion processes dominate, with an important year-to-year variability. For the 4 studied cycles in 
Ecuadorian part, they are $16,5,6.6$ et $14.510^{6}$ ton $\mathrm{yr}^{-1}$, and 19.8 ton $\mathrm{yr}^{-1}$ for the only one cycle studied in Peruvian part. These values show that during the studied period, approximately $47 \%$ of the TSS flux exited from the ecuadorian basin of Napo stemming from the erosion of andean foreland $\left(1,160 \mathrm{t} \mathrm{km}^{-2}\right.$ year $\left.^{-1}\right)$ located between FDO+SEB and ROC station.

Then, the Napo River enters the flat Amazon Plain where a transport process of TSS dominated, increase by the input coming essentialy from the two tributary of Aguarico and Curaray River. The last one tributary drains the Pastaza Megafan.

A discussion based on the comparing of these results with the geomorphologic and geodynamic characteristics of this Andean region, enables us to understand the origin and variability of the mass transfer processes. In the amazonian plain of Ecuador, the basin presents a relatively high slope $\left(35 \mathrm{~cm} \mathrm{~km}^{-1}\right)$. It is made up of very fine fluvial sediments. Taking in consideration the active and current uplift of the western foreland belt of the Amazon plain, these results confirm those other studies on geodynamics (conducted over a longer period). Since the end of Neogene and during Quaternary period, under the influence of the Andes uplifts, the foreland basin has presented erosion processes of the old sediments, which were deposited at a time when the slopes were less steep. Further downstream in the peruvian part of the Napo Basin, the index slope diminish significantly $\left(10-20 \mathrm{~cm} \mathrm{~km}^{-1}\right)$ between ROC and BEL and the sediment contribution of the intermediated drained area corresponds to $42.5 \%$ of the Napo River sediment yield at BEL. Here the sediment budget stays always high, with an excess of 19.8 ton $\mathrm{yr}^{-1} 1$ for the only one year studied. This positive budget probably comes from the two main tributaries of Aguarico and Curaray River, unfortunately poorly studied, and maybe also from the continuity of an erosion and/or transport process of TSS.

The opposite condition has been observed further South in the Madeira foreland basin (Guyot et al. 1996), where half of the sediment suspended load of the Beni/Mamore River settles 
between the Andean Piedmont of Bolivia and the Brazilian border. This basin presents a weaker slope of $8 \mathrm{~cm} \mathrm{~km}^{-1}$ in a region still marked by an active flexural subsidence. Further east, in the Central Amazon Flood Plain in Brazil, sedimentary processes are also observed with weaker slopes (3 to $0.3 \mathrm{~cm} \mathrm{~km}-1$, Laraque et al., 2005).

The combination of geodynamic phenomena (tectonism, volcanoes, earthquakes and landslides) common in this region, favours large sediment transfers, not only at present but also in the past. This is confirmed by the presence of incised terraces, mainly formed by volcanic materials (Bès de Berc, 2003).

\section{REFERENCES}

Aalto R., Dunne T., Guyot J.L. 2006. Geomorphic controls on Andean denudation rates. Journal of Geology, 114(1): 85-99.

Aalto R., Maurice-Bourgoin L., Dunne T., Montgomery D.R., Nittrouer C.A., Guyot J.L., 2003. Episodic sediment accumulation on Amazonian flood plains influenced by El Niño/Southern Oscillation. Nature 425: 493-496. DOI: 10.1038/Nature02002.

Baumgartner, A., and Reichel, E.,1975. The world water balance. Mean annual global continental and maritime precipitation, evaporation and runoff: Amsterdam, Elsevier, $176 \mathrm{p}$.

Baby P., Guyot J.L., Hérail G. (in press). Tectonic control, erosion and sedimentation of the Amazon Basin of Bolivia. Hydrological Processes.

Bernal, C., (personal communication).

Bernal C., Laraque L., Guyot J.L., Sondag F., Lagane C. 2007. Influence de l'activité volcanique dans la chimie du Napo : affluent de l'Amazone venant des Andes équatoriennes (Poster). Water quality and sediment behaviour of the future, IAHS, 
Perugia, July 2007.

Bès de Berc, 2003. Tectonique de chevauchement, surrection et incision fluviatile (exemple de la zone subandine equatorienne, haut bassin amazonien). $\mathrm{PhD}$ thesis, University of Toulouse. $181 \mathrm{pp}$

Bès de Berc, S., Soula, J. C., Baby, P., Souris, M., Christophoul, F. \& Rosero, J. 2005. Geomorphic evidence of active deformation and uplift in a modern continental wedgetop foredeep transition: example of the eastern Ecuadorian Andes. Tectonophysics.

Bourrel L., Darrozes J., Guyot J.L., Cristophoul F., Bondoux F., Paredes N., Pombosa R., Yerren J., Fuertes O., Mailler S. \& DeGenot V., 2007: Correlation between river slope and meandering variability (obtained by DGPS data) and morphotectonics for two Andean tributaries of the Amazon river: the case of Beni (Bolivia) and Napo (Ecuador-Peru) rivers (Poster), Hydrology of the Amazon, AGU Joint Assembly, Acapulco, Mexico, 22-25 May 2007.

Burgos, J. D., Baby, P., Christophoul, F., Soula, J. C. \& Rochat, P. 2004. Cuantificación de las erosiones terciaria y plio-cuaternaria en la parte sur de la Cuenca Oriente del Ecuador. Erosion rates during the Tertiary and Plio-Quaternary period in the South of the Ecuador Oriental basin. In: Geología de la Cuenca Oriental del Ecuador (Geology of Oriental Basin of Ecuador). IFEA, IRD, Petroproduccion, Lima, Peru. 115-130.

Cerón, C. 2004. Flux sédimentaires des bassins amazoniens d'Equateur - mémoire de DEA UPS Toulouse, $30 \mathrm{p}$.

Christophoul, F., Baby, P., Davila, C., 2002a. Stratigraphic response to a major tectonic event in a foreland basin : the Ecuadorian Oriente Basin from Eocene to Oligocene times. In : Tectonophysics. 281-298.

Christophoul, F., Baby, P., Soula, J.C., Rosero, M., Burgos, J., 2002b. Les ensembles fluviatiles néogènes du basin subandin d'Equateur et implications dynamiques. In : 
C.R.Geoscience 334. 1029-1037.

Cornelius Eji Uba, Christoph Heubeck, Carola Hulka. 2005. Facies analysis and basin architecture of the Neogene Subandean synorogenic wedge, southern Bolivia. In Sedimentary Geology 180 (2005) 91-123.

Crespo, E., Nyman, K. J. and O'Rourke, T.D. 1987. Stability of cut slopes in Ecuadorian volcaniclastic deposits. Proceedings $8^{\text {th }}$ PanAmerican Conference on Soil Mechanics and Foundation Engineering, Cartagena, Colombia, 3: 39-49.

Dunne, T., L. A. K. Mertes, R. H., Meade, J. E., Richey, and B. R. Forsberg. 1998. Exchanges of sediment between the flood plain and channel of the Amazon River in Brazil. Geological Society of America Bulletin 110: 450-467.

Eissen J.P., Le Pennec J.L. 2002. Rapport spécial sur le réveil explosif du volcan «El Reventador ». Unité de Recherche "Processus et Aléas Volcaniques” (UR 031), IRD.

Filizola, N. 2003. Transfert sédimentaire actuel par les fleuves amazoniens. Thèse de 1'UPS de Toulouse, France.

Filizola N., Guyot J.L. 2004. The use of Doppler technology for suspended sediment discharge determinations in the River Amazon. Hydrological Sciences Journal, 49(1) 143-153.

Fraizy, P., Armijos, E., Audin, L., Baby, P., Bondoux, F., Bourrel, L., Cerón, C., Darrozes, J., Espinoza, J.C., Guyot, J.L., Laraque, A., Lavado, W., Magat, P., Paredes, N., Pintaud, J.C., Pombosa, R., Pujos, F., Yerren, J. 2005. Reporte de la campaña EQ 52 (PE 16) RIO NAPO - Octubre 2004. 36 pa.

Gibbs R.J. 1967. The Geochemistry of the Amazon River System. Part I. The factors that control the salinity and the composition and concentration of the suspended solids. Geological Society of America Bulletin 78 : 1203-1232.

Gondran, R. 2004. Impact de l'éruption du Reventador sur la chimie de la phase dissoute du 
Rio Coca. (Rapport de stage LMTG-UPS-Toulouse).

Guyot, J.L., 1993. Hydrogéochimie des fleuves de l'Amazonie bolivienne. ORSTOM Ed., $261 \mathrm{p}$.

Guyot, J. L., Filizola, N., Quintanilla, J. \& Cortez, J. 1996. Dissolved solids and suspended sediment yields in the Rio Madeira basin, from the Bolivian Andes to the Amazon. In: Erosion and Sediment Yield: Global and Regional Perspectives (ed. by D. E. Walling \& B. W. Webb) (Proc. Exeter Symp., July 1996), 55-63. IAHS Publ. 236. IAHS Press, Wallingford, UK.

Guyot, J.L., Jouanneau, J.M., Wasson, G., 1999. Characterisation of river bed and suspended sediments in the Rio Madeira drainage basin (Bolivian Amazonia). Journal of South American Earth Sciences, 12 (1999), 401-410.

Guyot, J.L., Filizola, N., Laraque, A. 2005. Régime et bilan du flux sédimentaire de l'Amazone à Óbidos (Pará, Brésil) de 1995 à 2003 (The suspended sediment flux of the River Amazon at Obidos, Brazil, 1995-2003). In "Sediment Budgets 1" (D. E. Walling \& Arthur J. Horowitz, Eds), IAHS Publ. (Prooceding of 7th IAHS Assembly, Foz de Iguaçu, Brazil), N²91, 347-354.

Guyot J.L., Bazan H., Fraizy P., Ordonez J. 2007. Suspended sediment yields in the Amazon basin of Peru. Water quality and sediment behaviour of the future, IAHS, Perugia, July 2007.

Hall, M.L., 1991. The March 5, 1987 Ecuador Earthquakes-Mass Wasting and Socioeconomic Effects. The National Academic Press, Washington, DC.

Hsieh, M.L., Knuepfer, P.L.K., 2001. Middle-late Holocene river terraces in the Erhjen River basin, southwestern Taiwan-implications of river response to climate change and active tectonic uplift. Geomorphology 38, 337-372. 
Horton, B.K., De Celles, P.G. 2001. Modern and ancient fluvial megafans in the foreland basin system of the Central Andes, Southern Bolivia: implications for drainage network evolution of fold-thrust belts, Basin Res. 13 (2000) 43-63.

Hovius, N., 1998. Controls on sediment supply by large rivers, Relative Role of Eustasy, Climate, and Tectonism in Continental Rocks. Society of Sedimentary Geology. Special Publication No. 59. pp 3-16.

Keefer, D.K., Moseley, M.E., de France, S., 2003. A 38000-year record of floods and debris flows in the Ilo region of southern Peru and its relation to El Niño events and great earthquakes. Palaeogeogr. Palaeoclimatol. Palaeoecol. 194, pp 41- 77.

Laraque, A., Bricquet, J.P., Olivry, J.C., 1995. Transports solides et dissous du fleuve Congo (bilan de six années d'observations). Actes du colloque PEGI - Grands bassins fluviaux periatlantiques : Congo, Niger, Amazone - (INSU-CNRS-ORSTOM), Paris, France, du 22 au 24 novembre 1993, 217-228.

Laraque, A., Magat, P., Cerón C., Herredia, E. 2002. 24 ${ }^{\text {ta }}$ Comisión de aforos, muestreo de agua y sedimentos. Cuencas de los ríos Pastaza, Santiago, Curaray. código E24 : (0914 junio de 2002). $18 \mathrm{p}$.

Laraque, A., Cerón, C., Eissen, J.P.,Bourdon, E., Muñoz, T. 2002. Primer estudio limnologico de la laguna del volcan El Altar en los andes ecuatorianos. V Seminario Colombiano de Limnologia \& I Reunion Internacional de limnologia del Alto Amazonas. Leticia (Amazonas) Colombie - Mayo 20 a 24 de 2002.

Laraque, A., Cerón, C., Armijos, E., Pombosa, R., Magat, P. \& Guyot, J. L., 2004. Sediment yields and erosion rates in the Napo River Basin: an Ecuadorian Andean Amazon tributary. In: Sediment Transfer through the Fluvial System (ed. by V. Golosov, V. Belyaev \& D. E. Walling), 220-225. IAHS Publ. 288. IAHS Press, Wallingford, UK.

Laraque, A., Filizola, N., Guyot, J.L. 2005. Sediment budget in the Brazilian Amazon basin, 
based on a 10 days sampling procedure. In "Sediment Budgets 1" (D. E. Walling \& Arthur J. Horowitz, Eds), IAHS Publ. (Prooceding of 7th IAHS Assembly, Foz de Iguaçu, Brazil), $\mathrm{N}^{\circ} 291,250-258$.

Laraque, A., Ronchail J., Cochonneau G., Pombosa R., Guyot, J.L. (2007). Heterogeneous distribution of rainfall and discharge regimes in the Ecuadorian Amazon Basin. Jo. of Hydrometeorology, vol. 8, $\mathrm{n}^{\circ}$ 6, december 2007, pa. 1364-1381.

Leeder, M.R., Harris, T., Kirby, M.J., 1998. Sediment supply and climate change: implications for basin stratigraphy. Basin Res. 10, 7 - 18 .

Milliman, J.D., and Meade, R.H., 1983. World-Wide Delivery of River Sediment to the Oceans. Journal of Geology. Vol 91, No 1, p. 1-21.

Meade R.H., Dunne T., Richey J.E., Santos U.M., Salati E. 1985. Storage and Remobilization of suspended Sediment in the lower Amazon River of Brazil. Science $228: 488-490$.

Molinier, M., Guyot, J.L., De Oliveira, E., Guimarães, V., 1996. Les regimes hydrologiques de l'Amazone et de ses affluents. In L'hydrologie tropicale : géoscience et outil pour le développement (Actes de la conférence de Paris, mai, 1995) IAHS Publ. $\mathrm{N}^{\circ} 238$, 209-221.

Montgomery D., Balco, G., Willett, S.D., 2001. Climate, tectonics, and the morphology of the Andes. Geological Society of America, v. 29, nº7, p. 579-582.

Monzier, M., Robin, C., Samaniego, P., Hall, M.L., Cotton, J., Mothes, P., Arnaud, N., 1999. Sangay Volcano, Ecuador; structural development, present activity and petrology. J. Volcanol. Geotherm. Res. 90, 49-79.

Moreira-Turcq P., Jouanneau J.M., Turcq B., Seyler P., Weber O., Guyot J.L. 2004. Carbon sedimentation at Lago grande de Curuai, a floodplain lake in the low Amazon region: insights into sedimentation rates. Palaeogeography, Palaeoclimatology, Palaeoecology 214(1/2): 27-40. 
Okusa, S, Hakuno, M., Michuie, M., 1989. Distribution of factors of safety for natural slope stability - an example of Ecuador. In: Proc., Japan-China Symp. on Landslides and Debris Flows, Niigata, 3 October, Tokyo, 5 October, The Japan Landslide Soc . and The Japan Soc. of Erosion Control Eng. 273-278.

Räsänen, M., Neller, R., Salo, J., Jungner, H., 1992. Recent and ancient fluvial deposition systems in the Amazonian foreland basin, Peru. Geol. Mag. 129, 293- 306.

Restrepo, J.D., Kjerfveb, B., Hermelina, M., Restrepo, J.C., 2006. Factors controlling sediment yield in a major South American drainage basin: the Magdalena River, Colombia. Journal of Hydrology 316 (2006) 213-232.

Schuster, R.L., 1996. The 25 most catastrophic landslides of the 20th century, in Chacon, Irigaray and Fernandez (eds.), Landslides, Proc. Of the 8th International Conf. \& Field Trip on Landslides, Granada, Spain, 27-28 Sept. Rotterdam: Balkema

Weng, C., Bush, M.B., Athens, J.S., 2002. Holocene climate change and hydrach succession in lowland Amazonian Ecuador. Rev. Palaeobot. Palynol. 120, 73- 90.

Wesselingh, F.P., Guerrero, J., Räsänen, M., Romero Pitmann, L. and Vonhof, H., 2006. Landscape evolution and depositional processes in the Miocene Amazonian Pebas lake/wetland system: evidence from exploratory boreholes in northeastern Peru. Scripta Geologica, v. 133: p. 323-361.

Yepes, H., Chatelain, J.-L., Guillier, B., Alvarado, A., Egred, J., Ruiz, M., Segovia, M., 1996. The Mw 6.8 Macas earthquake in the Subandean Zone of Ecuador, October 3, 1995. Seismol. Res. Lett. 67, 27-32.

Zevallos O., Plaza Nieto, A., F., G., Klinkicht Sojos, S. 1993. Sin plazo para la esperanza (reporte sobre el desastre de la Josefina-Ecuador). Ed. EPN. 348 p.

Acknowledgements We would like to thank participants in HYBAm project from Ecuador 
and Peru, and their institutions of origin: INAMHI, IRD, SENAMHI. The efforts of the INOCAR team and also of Magat, P., Fraizy, P., Pombosa, P., allowed the successful of the Napo'04 scientific field trip.

Correspondence and request for materials should be adressed to alain.laraque@ird.fr. 


\section{List of Figure}

Fig. 1 Location of the Napo basin and its reference stations $(\mathrm{SEB}=$ San Sebastian St., FDO = Francisco de Orellana St., ROCA = Nuevo Rocafuerte St., CLO = Santa Clotilde St., BEL = Bellavista St.) and sampling point of the October 2004 crossing field.

Legend: continuous line $=$ limit of Amazon basin; dot line $=$ limit between Andes and Amazonian plain

Fig. 2 Mean rainfall regime in the Napo basin (1964-1998)

Fig. 3 Longitudinal profile of Napo River is represented by a grey line; while slope curve is represented by a black line. The proportion of sand, water and vegetated island in the Napo River is presented in two reaches FDO $-\mathrm{X}$ (top) and $\mathrm{X}-\mathrm{ROC}$ (down). X's coordinate: $0^{\circ} 26^{\prime} 39.16^{\prime \prime} \mathrm{S} / 76^{\circ} 14^{\prime} 51.05^{\prime \prime} \mathrm{W}$

Fig. 4 Relation between superficial and mean TSS concentration in the section (in $\mathrm{mg}^{-1}$ ) at the 3 gauging station studied.

Fig. 5 a) Monthly budget downstream (ROC) - upstream (SEB+FDO) of TSS fluxes at ROC for the studied period;

b) Monthly budget downstream (BEL) - upstream (ROC) of TSS fluxes at BEL for the common studied period;

legend : TSS histogram in $10^{3}$ ton $\mathrm{d}^{-1}$ (positive values = erosion process, negative values $=$ sedimentation process); monthly discharge curve (Q) in $\mathrm{m}^{3} \mathrm{~s}^{-1} ;$ abscissas in month-year.

Fig. 6 Cumulative (Cum) curve of Q (in $\mathrm{m}^{3} \mathrm{~s}^{-1}$ - circle), TSS concentration (in $\mathrm{mg}^{-1}$ - square) and TSS fluxes (in $10^{3}$ ton $\mathrm{d}^{-1}$ - triangle) during the period studied at the SEB st.

Fig. 7 Monthly a) hydrografs (in $\mathrm{m}^{3} \mathrm{~s}^{-1}$ ) and b) TSS concentration (in $\mathrm{mg}^{-1}$ ) at the 3 gauging station studied.

Fig. 8 Spatial variations of percentage in sand, water and vegetated island for two reach: FDO-X and X-ROC 


\section{List of Table}

Tab. 1 Presentation of the drainage basin studied with location of gauging stations.

Tab. 2 Interannual Values : minimum, mean and maximum of daily and monthly discharge $\left(\mathrm{m}^{3} \mathrm{~s}^{-1}\right), 10$ days TSS load and monthly TSS load $\left(\mathrm{mg} \mathrm{l}^{-1}\right)$, daily and monthly TSS yield (ton $\mathrm{d}^{-1}$ ), at the Gauging Station studied.

Tab. 3 Annual Discharges ( $\mathrm{Q}$ in $\mathrm{m}^{3} \mathrm{~s}^{-1}$ ), TSS load (in $\mathrm{mg}^{-1}$, ton $\mathrm{d}^{-1}$, ton $\mathrm{yr}^{-1}$, ton $\mathrm{km}^{2} \mathrm{yr}^{-1}$ ), at the Gauging Station studied.

Tab. 4 Data from October 2004 field sampling crossing along Napo River: latitude, longitude, distance from the Napo mouth $(\mathrm{km})$ and altitude $(\mathrm{m})$, TSS load concentration $\left(\mathrm{mg} \mathrm{l}^{-1}\right)$, measured discharges $\left(\mathrm{Q}\right.$ in $\left.\mathrm{m}^{3} \mathrm{~s}^{-1}\right)$, TSS fluxes \& annual upstream-downstream budget (TSS in ton $\mathrm{d}^{-1}$ ) between the gauging stations studied. For sampling code, see fig. 1. 




Figure 1 - Location of the Napo basin and its reference stations (SEB = Coca river at San Sebastian, FDO $=$ Napo river at Francisco de Orellana, ROCA $=$ Napo river at Nuevo Rocafuerte, $\mathrm{CLO}=$ Napo river at Santa Clotilde, BEL = Napo river at Bellavista).

Legend: continuous line $=$ limit of Amazon basin; dot line $=$ limit between Andes and Amazonian plain. 


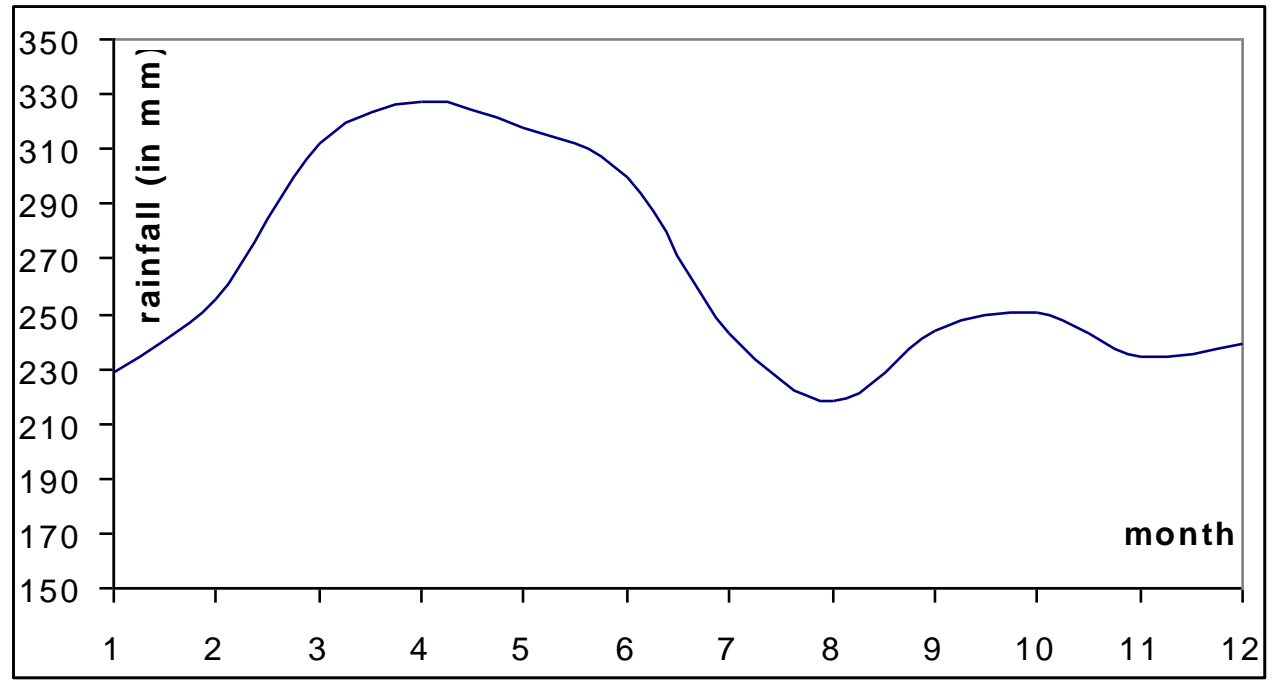

Figure 2 - Mean annual rainfall regime in the Napo basin (1964-1998) 




Figure 3 - Morphology of Napo River in the Amazonian Plain. Longitudinal profile is represented by a gray line; while slope curve is represented by a black line; $\mathrm{X}=\left(0^{\circ} 26^{\prime} 39.15^{\prime \prime} \mathrm{S} ; 76^{\circ} 14^{\prime} 51.05^{\prime \prime} \mathrm{W}\right)$. 


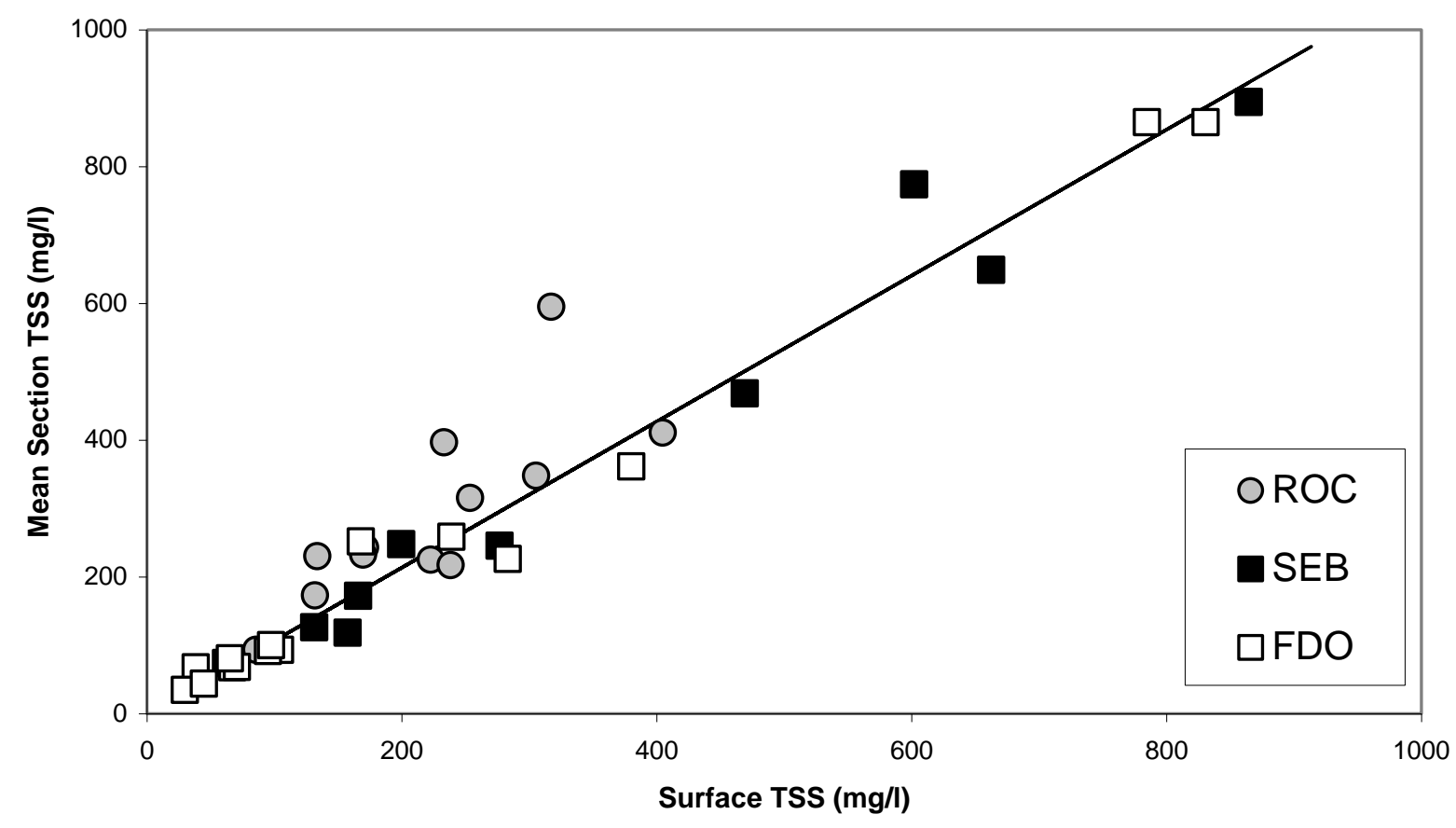

Figure 4 - Relation between superficial and mean TSS concentration in the section (in $\mathrm{mg}^{-1}$ ) at the 3 gauging station studied (ROC, SEB, FDO). 


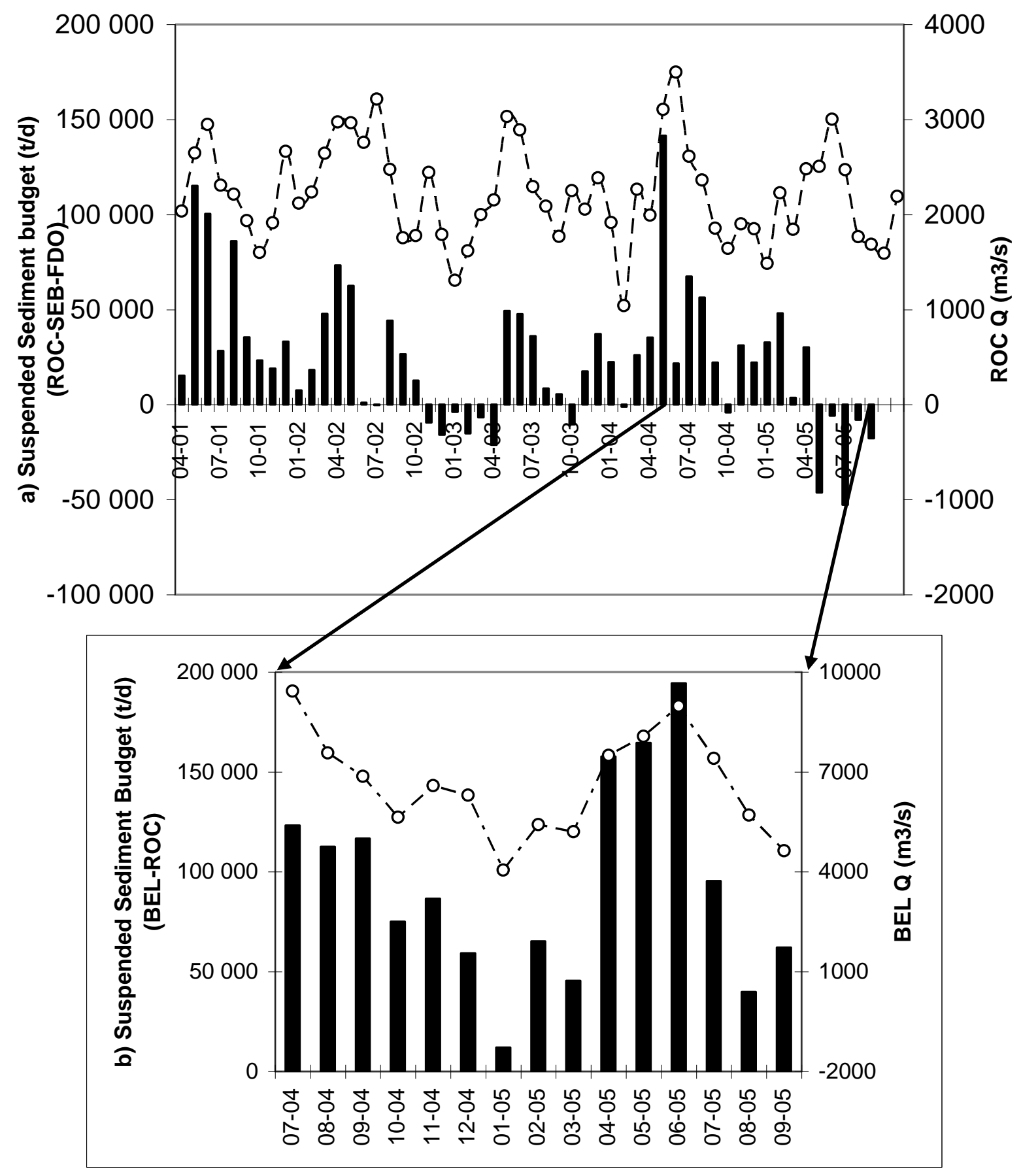

Figure 5 a) Monthly budget downstream (ROC) - upstream (SEB+FDO) of TSS fluxes at ROC for the studied period;

b) Monthly budget downstream (BEL) - upstream (ROC) of TSS fluxes at BEL for the common studied period;

legend : TSS histogram in $10^{3}$ ton $\mathrm{d}^{-1}$ (positive values = erosion process, negative values $=$ sedimentation process); monthly discharge curve $(\mathrm{Q})$ in $\mathrm{m}^{3} \mathrm{~s}^{-1}$; abscissas in month-year. 

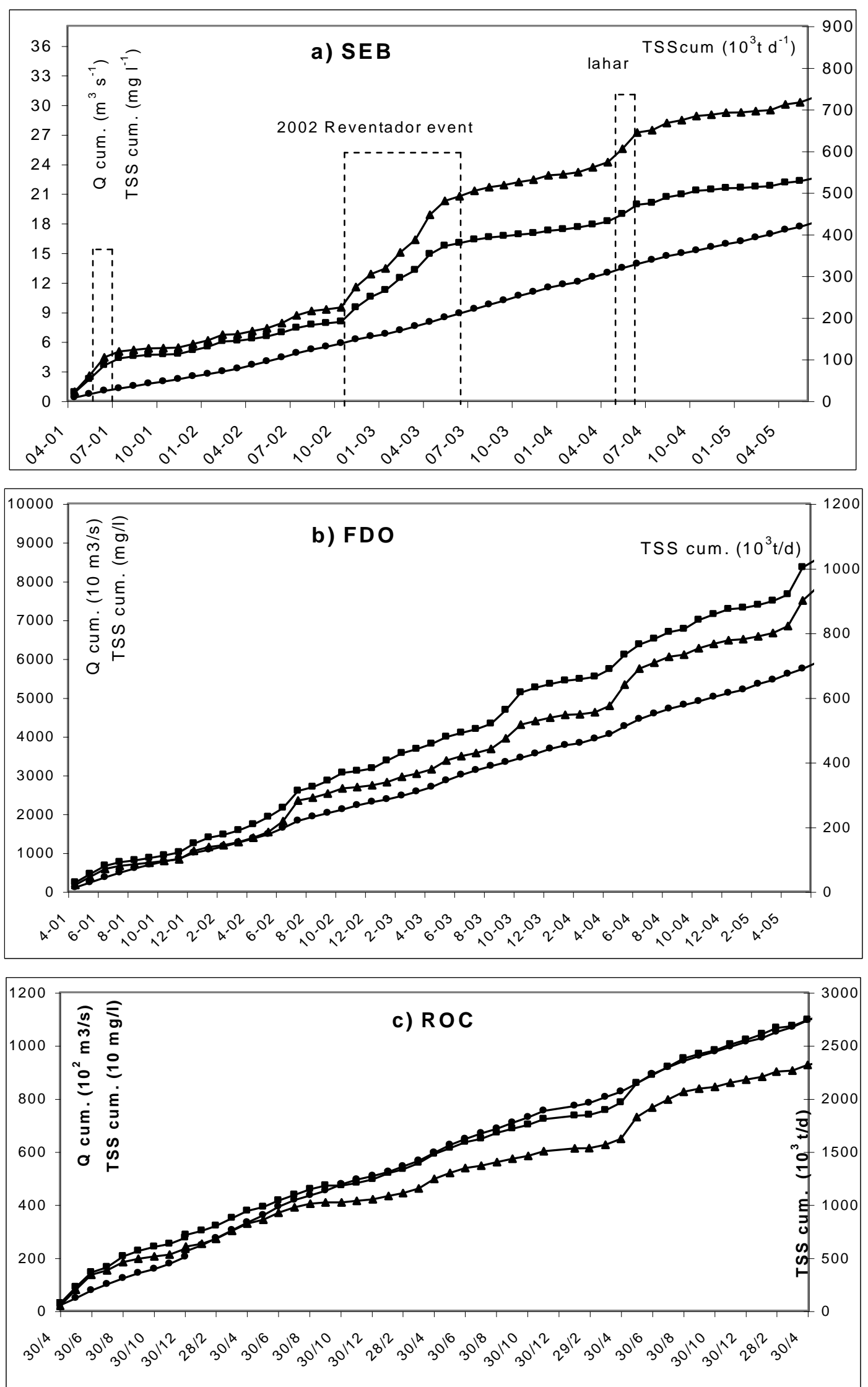

Figure 6 - Cumulative (Cum) curve of Q (in $\mathrm{m}^{3} \mathrm{~s}^{-1}$ - circle), TSS concentration (in $\mathrm{mg}^{-1}$ square) and TSS fluxes (in $10^{3}$ ton $\mathrm{d}^{-1}$ - triangle) during the period studied at SEB. 


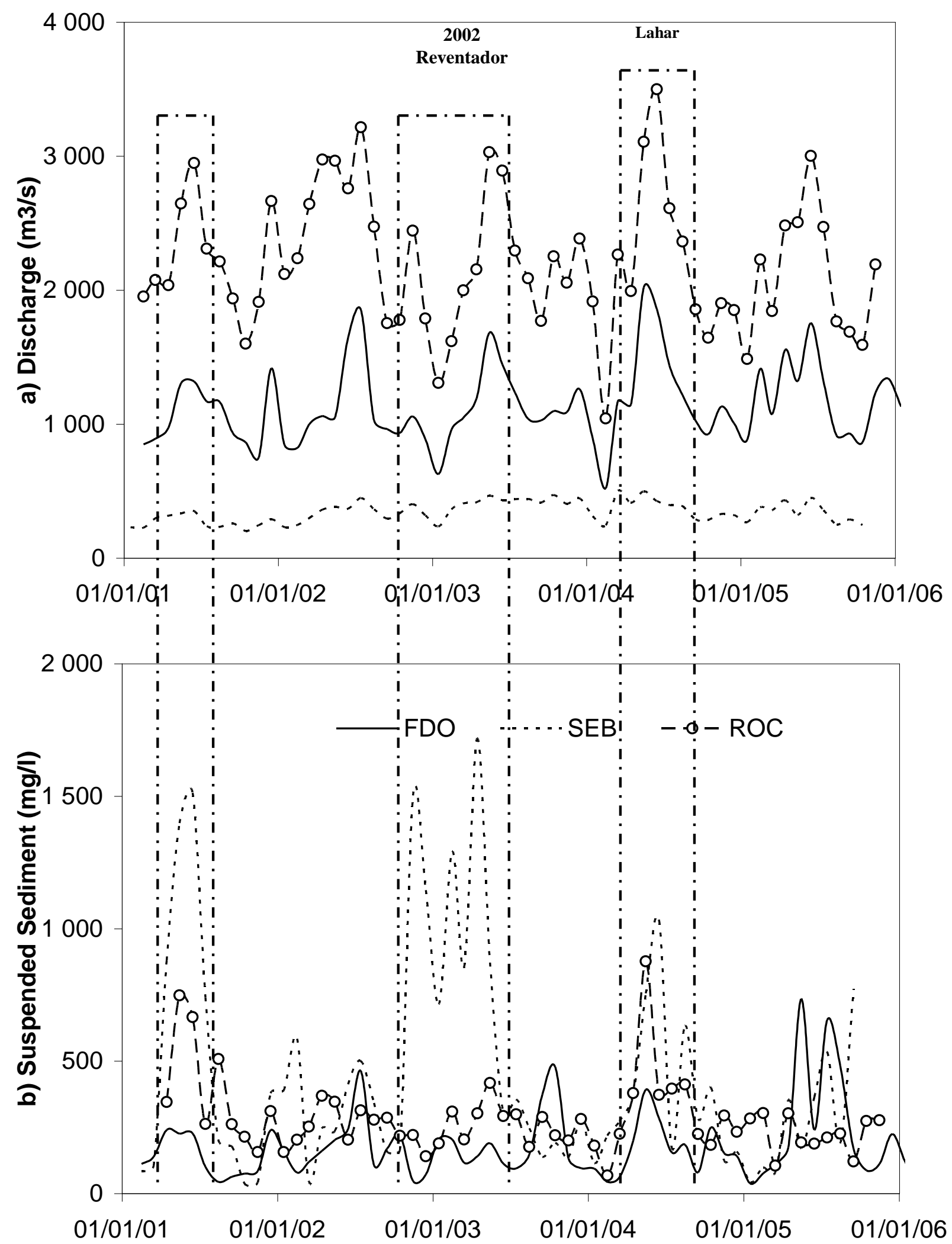

Figure 7 Monthly a) hydrografs (in $\mathrm{m}^{3} \mathrm{~s}^{-1}$ ) and b) TSS concentration (in $\mathrm{mg}^{-1}$ ) at the 3 gauging station studied. 




Figure 8 - Spatial variation of percentage in sand, water and vegetated island for two reach: FDO-X and X-ROC (see Fig. 3) 
Table 1 - Presentation of the drainage basin studied with location of gauging stations.

\begin{tabular}{|c|c|c|c|c|c|c|c|c|c|c|c|c|}
\hline \multirow{3}{*}{$\begin{array}{l}\text { Code } \\
\text { Station }\end{array}$} & \multirow{3}{*}{ Gauging station } & \multirow{3}{*}{ River } & \multirow{3}{*}{$\begin{array}{c}\text { Latitude } \\
\text { (degree) }\end{array}$} & \multirow{3}{*}{$\begin{array}{c}\text { Longitude } \\
\text { (degree) }\end{array}$} & \multicolumn{4}{|c|}{ Altitud Basin area } & \multirow{3}{*}{$\begin{array}{l}\text { Distance } \\
\text { from mouth } \\
(\mathrm{km})\end{array}$} & \multirow{3}{*}{$\begin{array}{l}\text { Study } \\
\text { period }\end{array}$} & \multirow{3}{*}{$\begin{array}{c}\text { slope }^{(3)} \\
\left(\mathrm{cm} \mathrm{km}^{-1}\right)\end{array}$} & \multirow{3}{*}{$\begin{array}{l}\text { Section for } \\
\text { slope data }\end{array}$} \\
\hline & & & & & & (2) & & charge & & & & \\
\hline & & & & & (m) & $\left(\mathrm{km}^{2}\right)$ & $\left(\mathrm{m}^{3} \mathrm{~s}^{-1}\right)$ & $\left(1 \mathrm{~s}^{-1} \mathrm{~km}^{2}\right)$ & & & & \\
\hline SEB & San Sebastian & oca & -0.343 & -77.007 & 290 & 5,270 & 350 & 66 & 870 & $01 / 2001-10 / 2005$ & 38.8 & ROC-SEB \\
\hline FDO & Francisco de Orellana & Napo & -0.473 & -76.983 & 262 & 12,440 & 1,130 & 91 & 850 & $01 / 2001-11 / 2005$ & 30.4 & ROC-FDO \\
\hline ROC & Rocafuerte & Napo & -0.917 & -75.396 & 18 & 26,860 & 2,210 & 82 & 6 & $01 / 2001-12 / 2005$ & 17.0 & CLO-ROC \\
\hline CLO & Santa Clotilde & Napo & -2.486 & -73.674 & 12 & 85,770 & 5,700 & 66 & 280 & $01 / 2004-12 / 2005$ & 12.0 & BEL-CLO \\
\hline BEL & Bellavista & Napo & -3.478 & -73.076 & 106 & 100,520 & 6,270 & 62 & 70 & 01/2004-02/2006 & & \\
\hline
\end{tabular}

(1) = DGPS data from Fraizy et al., (2005).

(2) $=$ from SRTM extraction.

(3) = Bourrel, L., et al., (2007). 
Table 2 - Interanual Values : minimum, mean and maximum of daily and monthly discharge $\left(\mathrm{m}^{3} \mathrm{~s}^{-1}\right), 10$ days TSS load and monthly TSS load $\left(\mathrm{mg} \mathrm{l}^{-1}\right)$, daily and monthly TSS yield $\left(\right.$ Ton $\mathrm{d}^{-1}$ ), at the gauging stations studied

\begin{tabular}{|c|c|c|c|c|c|}
\hline & & SEB & FDO & ROC & BEL \\
\hline \multirow{5}{*}{$\begin{array}{l}\text { Daily Discharge } \\
\qquad\left(\mathrm{m}^{3} \mathrm{~s}^{-1}\right)\end{array}$} & Mean & 345 & 1,134 & 2,207 & 6,265 \\
\hline & Max & 724 & 5,055 & 5,087 & 12,360 \\
\hline & Min & 103 & 381 & 954 & 1,285 \\
\hline & Max / Min & 7 & 13 & 5 & 10 \\
\hline & Values number & 1,765 & 1,793 & 1,801 & 789 \\
\hline \multirow{5}{*}{$\begin{array}{l}\text { Monthly Discharge } \\
\qquad\left(\mathrm{m}^{3} \mathrm{~s}^{-1}\right)\end{array}$} & Mean & 344 & 1,140 & 2,217 & 6,267 \\
\hline & $\operatorname{Max}$ & 502 & 2,020 & 3,499 & 11,090 \\
\hline & Min & 202 & 523 & 1,043 & 1,426 \\
\hline & Max / Min & 2 & 4 & 3 & 8 \\
\hline & Values number & 58 & 58 & 58 & 25 \\
\hline \multirow{5}{*}{$\begin{array}{c}10 \text { day TSS load } \\
\left(\mathrm{mg} \mathrm{l}^{-1}\right)\end{array}$} & Mean & 431 & 161 & 218 & 125 \\
\hline & Max & 2,806 & 956 & 1,403 & 341 \\
\hline & Min & 10 & 2 & 5 & 32 \\
\hline & Max / Min & 281 & 478 & 281 & 11 \\
\hline & Values number & 167 & 175 & 165 & 76 \\
\hline \multirow{5}{*}{$\begin{array}{l}\text { Monthly TSS load } \\
\left(\mathrm{mg} \mathrm{l}^{-1}\right)\end{array}$} & Mean & 467 & 190 & 291 & 235 \\
\hline & $\operatorname{Max}$ & 1,766 & 728 & 912 & 348 \\
\hline & Min & 37 & 37 & 69 & 139 \\
\hline & Max / Min & 48 & 20 & 13 & 3 \\
\hline & Values number & 56 & 57 & 56 & 19 \\
\hline \multirow{5}{*}{$\begin{array}{l}\text { Daily TSS yield } \\
\quad\left(\operatorname{ton} d^{-1}\right)\end{array}$} & Mean & 14,235 & 19,982 & 58,861 & 133,395 \\
\hline & $\operatorname{Max}$ & 116,330 & 355,510 & 551,590 & 424,410 \\
\hline & Min & 168 & 229 & 3,385 & 36,086 \\
\hline & Max / Min & 694 & 1,552 & 163 & 12 \\
\hline & Values number & 1,751 & 1,773 & 1,739 & 618 \\
\hline \multirow{5}{*}{$\begin{array}{c}\text { Monthly TSS yield } \\
\left(\text { ton }^{-1}\right)\end{array}$} & Mean & 14,607 & 20,146 & 59,332 & 132,762 \\
\hline & $\operatorname{Max}$ & 63,447 & 83,259 & 244,780 & 246,440 \\
\hline & Min & 639 & 2,059 & 6,222 & 48,476 \\
\hline & Max / Min & 99 & 40 & 39 & 5 \\
\hline & Values number & 56 & 57 & 56 & 19 \\
\hline
\end{tabular}


Table 3 - Annual Discharges ( $\mathrm{Q}$ in $\mathrm{m}^{3} \mathrm{~s}^{-1}$ ), TSS load (in $\mathrm{mg}^{-1}$, ton $\mathrm{d}^{-1}$, ton $\mathrm{yr}^{-1}$, ton $\left.\mathrm{km}^{2} \mathrm{yr}^{-1}\right)$, at the gauging station studied

\begin{tabular}{|c|c|c|c|c|c|c|c|c|}
\hline & Studied Period & SEB & FDO & ROC & BEL & SEB+FDO & ROC-FDO-SEB & BEL-ROC \\
\hline Discharge & $04 / 2001-03 / 2002$ & 270 & 1,047 & 2,272 & & 1,317 & 955 & \\
\hline \multirow[t]{4}{*}{$\left(m^{3} s^{-1}\right)$} & $04 / 2002-03 / 2003$ & 357 & 1,093 & 2,256 & & 1,449 & 807 & \\
\hline & 04/2003-03/2004 & 416 & 1,138 & 2,179 & & 1,554 & 624 & \\
\hline & 04/2004-03/2005 & 363 & 1,261 & 2,199 & 6976 & 1,624 & 575 & 4,777 \\
\hline & Mean value & 351 & 1,135 & 2,227 & 6976 & 1,486 & 740 & 4,777 \\
\hline TSS & $04 / 2001-03 / 2002$ & 545 & 140 & 344 & & 180 & 53 & \\
\hline \multirow[t]{4}{*}{$\left(\mathrm{mg} \mathrm{l}^{-1}\right)$} & $04 / 2002-03 / 2003$ & 635 & 179 & 260 & & 230 & 20 & \\
\hline & 04/2003-03/2004 & 415 & 168 & 251 & & 178 & 34 & \\
\hline & 04/2004-03/2005 & 352 & 177 & 352 & 224 & 179 & 80 & 13 \\
\hline & Mean value & 487 & 166 & 302 & 224 & 192 & 45 & 13 \\
\hline TSS & $04 / 2001-03 / 2002$ & 14,050 & 13,404 & 71,571 & & 27,454 & 44,117 & \\
\hline \multirow[t]{4}{*}{$\left(\operatorname{ton} d^{-1}\right)$} & $04 / 2002-03 / 2003$ & 19,890 & 18,617 & 52,590 & & 38,507 & 14,083 & \\
\hline & 04/2003-03/2004 & 15,318 & 16,708 & 50,158 & & 32,026 & 18,132 & \\
\hline & 04/2004-03/2005 & 12,081 & 21,519 & 73,422 & 127562 & 33,600 & 39,822 & 54,140 \\
\hline & Mean value & 15,335 & 17,562 & 61,935 & 127562 & $\mathbf{3 2 , 8 9 7}$ & 29,038 & 54,140 \\
\hline TSS & $04 / 2001-03 / 2002$ & 5,1 & 4,9 & 26,1 & & 10,0 & 16,1 & \\
\hline \multirow{4}{*}{$\left(x 1^{6}\right.$ ton $\left.\mathrm{yr}^{-1}\right)$} & $04 / 2002-03 / 2003$ & 7,3 & 6,8 & 19,2 & & 14,1 & 5,1 & \\
\hline & 04/2003-03/2004 & 5,6 & 6,1 & 18,3 & & 11,7 & 6,6 & \\
\hline & 04/2004-03/2005 & 4,4 & 7,9 & 26,8 & 46,6 & 12,3 & 14,5 & 19,8 \\
\hline & Mean value & 5,6 & 6,4 & 22,6 & 46,6 & 12,0 & 10,6 & 19,8 \\
\hline TSS & $04 / 2001-03 / 2002$ & 973 & 393 & 973 & & 1,366 & 1,760 & \\
\hline \multirow[t]{4}{*}{$\left(\right.$ ton $\left.\mathbf{k m}^{2} \mathbf{y r}^{-1}\right)$} & $04 / 2002-03 / 2003$ & 1,378 & 546 & 715 & & 1,924 & 562 & \\
\hline & 04/2003-03/2004 & 1,061 & 490 & 682 & & 1,551 & 723 & \\
\hline & 04/2004-03/2005 & 837 & 631 & 998 & 463 & 1,468 & 1,589 & 268 \\
\hline & Mean value & 1,062 & 515 & 842 & 463 & 1,577 & 1,158 & 268 \\
\hline
\end{tabular}


Table 4 - Data from octuber 2004 field sampling crossing along Napo river : latitude, longitude, distance from the Napo mouth (km) and altitude (m), TSS load concentration ( $\left.\mathrm{mg} \mathrm{l}^{-1}\right)$, measured discharges $\left(\mathrm{Q}\right.$ in $\left.\mathrm{m}^{3} \mathrm{~s}^{-1}\right)$, TSS fluxes \& anual upstream-downstream budget (TSS in Ton $\mathrm{d}^{-1}$ ) between the gauging stations studied. For sampling code, see Fig. 1.




